\title{
オノマトペと質感印象の結び付きに着目した商品 検索への画像・テキスト情報活用の可能性
}

\section{Possibility to Use Product Image and Review Text Based on the Association between Onomatopoeia and Texture}

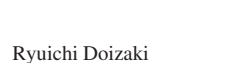 \\ 電気通信大学大学院情報理工学研究科 \\ Graduate School of Informatics and Engineering, The University of Electro-Communications \\ r.doizaki@uec.ac.jp

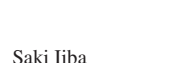 \\ (同上) \\ i1130005eedu.cc.uec.ac.jp \\ 岡谷 貴之 \\ 東北大学大学院情報科学研究科 \\ Graduate School of Information Sciences, TOHOKU University \\ okatani@vision.is.tohoku.ac.jp \\ 坂本 真樹
Maki Sakamoto \\ 電気通信大学大学院情報理工学研究科 \\ Graduate School of Informatics and Engineering, The University of Electro-Communications \\ sakamoto@inf.uec.ac.jp
}

keywords: onomatopoeia, texture, product image, review text, SIFT, color, text

\begin{abstract}
Summary
With the widespread use of online shopping in recent years, consumer search requests for products have become more diverse. Previous web search methods have used adjectives as input by consumers. However, given that the number of adjectives that can be used to express textures is limited, it is debatable whether adjectives are capable of richly expressing variations of product textures. In Japanese, tactile and visual textures are easily and frequently expressed by onomatopoeia, such as " fuwa-fuwa" for a soft and light sensation and" kira-kira " for a glossy texture. Onomatopoeia are useful for understanding not only material textures but also a user's intuitive, sensitive, and even ambiguous feelings evoked by materials. In this study, we propose a system to rank FMD images corresponding to texture associated with Japanese onomatopoeia based on their symbolic sound associations between the onomatopoeia phonemes and the texture sensations. Our system quantitatively estimates the texture sensations of input onomatopoeia, and calculates the similarities between the users' impressions of the onomatopoeia and those of the images. Our system also suggests the images which best match the input onomatopoeia. An evaluation of our method revealed that the best performance was achieved when the SIFT features, the colors of the images, and text describing impressions of the images were used.
\end{abstract}

\section{1.は じめに}

$1 \cdot 1$ インターネットショッピングの現状と商品検索 近年，インターネットの爆発的な普及に伴い, 我々の 消費行動は大きく変化している . 2013 年度にアイブリッ ジ株式会社*1 ${ }^{*}$, 全国 20 歳から 99 歳の男女 300 名に対 して実施した調査によると，「インターネットショッピン

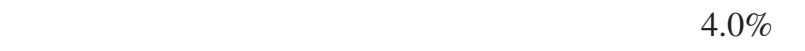
あり，残りの $96.0 \%$ 「利用経験がある」と回答してい る.また, 兴の利用頻度は年々増加傾向にあり, 月に 1 回 程度の利用が $25.7 \%$, 月に 2,3 回程度の利用が $27.7 \%$, 週に 1 回以上の利用が $6.7 \%$ であった .さらに，経済産 業省*2 の統計によると，2012 年度の消費者向け電子商取

*1 http://www.ibridge.co.jp/

*2 http://www.meti.go.jp/
引 (Electronic commerce, 以下 EC) の市場は, 対前年 比 $12.5 \%$ 増の 9.5 兆円となり, 拡大の一途を辿っている. 実際にユーザの 45.8\%は「インターネットショッピング の方が実店舗よりも消費意欲か増加している」と回答し ている．このようにECサイトを利用する消費者が増え る一方で, 多種多樣な商品を取り扱う Amazon *3などの $\mathrm{EC}$ サイトでは, 無数の商品の中からユーザの好みに合う 商品を見つけることの難しさか指摘されている [高玉 13] . したがって従来研究では, ユーザが所望する商品を効率 的に推薦する樣々な手法が提案されており [醍酤 95, 清 水 08 , 加藤 05 , 高玉 13 , 中辻 13], 弚の検索性能は年々高 まっている [Broder 06] . これまでに提案されてきた推薦 手法の多くは, 商品の価格や機能等とユーザの好みを記 したプロファイルを比較して商品を推薦する内容ベース 
フィルタリング [神嶌 08] と，ユーザと類似した好みを 持つ別のユーザの購入商品を推薦する協調フィルタリン グ [Resnick 94, Linden 03] のふたつに分類することがで きる [Herlocker 04, Adomavicius 05, Riecken 00] .これ ら従来の手法を EC サイトに適用する場合 , ユーザの興 味に即したプロファイル作成が難しいことや [土方 04]， 潜在的に興味を持っている情報が推薦されにくいといっ た問題がある [加藤 05] . また [服部 11] によると，現在 多くの EC サイトで採用されている協調フィルタリング に関して, ユーザにとって既知のアイテムが推薦される ことが多く, 満足な推薦結果を得ることができない場合 があることか指摘されている [Ziegler 05, 清水 08] . ユー ザの好みを把握することの難しさに関して , 情報に対す る人間の要求は単純ではなく, ユーザをも推薦システム の系の一部として利用することの必要性や [土方 07] , 人 は必ずしも明確な商品イメージを持ってはおらず, ぼん やりとした願望の寄せ集めのようなものを心の中に持っ て購買を行うことが指摘されている [醍醐 95] .

実際, 2007 年度にボーダーズ株式会社 ${ }^{* 4}$ が, 全国の 16 歳から 59 歳の男女 475 名に対して実施した調査による と、購入したい特定の商品が決定した段階でEC サイト を訪れる」と回答したユーザは全体の $42.5 \%$ であり，「目 的とする具体的な商品は決まっていないが EC サイトに 訪れることがある」と回答したユーザは $26.3 \%$ であった . したがって , ユーザの 4 人に 1 人が EC サイトにおける 商品購入に明確な目的を持っていないことが示されてい る . 漠然としたイメージのみで商品を探すユーザにとっ て, 商品の具体的な特徵を入力とする現在の検索方法で は, 商品の選択の幅を狭めてしまい, 新しい商品と出会 う機会が減る可能性がある. 現在一般的に用いられてい る特定の商品特徵を入力とするキーワード検索方法は， ユーザの多樣化したニーズや曖昧なイメージに対しては 十分に機能していないと考えられるため, ユーザにとつ て未知でかつ意外性のある多樣なアイテムを推薦するこ とは, 情報推薦手法にとって解決すべき重要な課題と言 える [服部 11] .

また，消費者か商品購入を決定する要因について ,2007 年度に独立行政法人中小企業基盤整備機構 $* 5$ が, 全国 20 歳以上の男女 2000 名に対して実施した調査によると, 商 品購入を決定する際に重視するポイントとして，1 位が $\ulcorner$ 色・柄・模樣・形などのデザイン」，2 位が「手触りや 見た目からの風合いなどの質感」であり, 消費者は, 商 品に対してデザインや質感といった感性的な側面を重視 する傾向が強いことが示されている．

消費者は商品購入の決定において, 商品の手触りや風 合いといった「質感」を重視する傾向にあるが, 現状の インターネットショッピングでは, 商品の質感を正確に 捉えることは難しいため, ユーザが求める質感イメージ

*4 http://borders.jp/

*5 http://www.smrj.go.jp/
に相応しい商品を提案することにより，従来よりも満足 度の高い購買行動を実現できると考えられる。

\section{$1 \cdot 2$ 人の感性を考慮した情報検索}

近年 , マルチメディアコンテンツのイメージや印象と いった主観的な基準に対応して，個人に適したコンテン ツを検索する「感性検索」と呼ばれる研究が盛んに行わ れている [今中 98, 荻野 06] . 感性検索とは，感覚や感性 を表現する言語を入力することで, 目的とする商品情報 を検索できる技術である [吉川 98] . 先に述べたように， 既存のキーワード検索では, 具体的な商品特徵を入力し なければ，目的とする情報を取得することが難しいとさ れる. 兴の一方で, 感性検索は, 求める商品の曖昧なイ メージから情報を取得することができ, 求める情報の知 識がしいユーザでも使いやすく, 目的か定まっていない ユーザの潜在ニーズを掘り起こすことができる [吉川 98] . Web ページを対象とした感性検索の多くは, 形容詞を検 索クエリとし , 入力された形容詞と Web テキストに含ま れる単語とのマッチングによって，谷の人の感性に適し た Web ページの検索を行っている [Yanbe 07, Heymann 08] .

形容詞を入力とした画像検索に関する従来研究では， 色彩と感性の結びつきの強さから，画像が持つ視覚的特 徵として色特徵を扱う研究が多く[木本 99 , 黑田 07, 栗 田 92] , 結果として, 画像にマッピングされる形容詞は, 「明るい・ゴージャスな」といった視覚的な印象を表すも のが多く見られる．关の一方で，画像に写る物体の触感 を表す表現（「湿った」「滑らかな」など）を入力とした 画像検索は少なく，質感から喚起される視覚印象と触覚 印象の両方を画像と対応させた検索手法は見られなかっ た，光こで本研究では，質感評価システム [清水 14]（後 述) が持つ，43 対の形容詞尺度による質感印象の定量化 を通して，質感から喚起される視覚印象と触覚印象をと もに抽出する手法を検討する．

\section{$1 \cdot 3$ 質感認識におけるオノマトペの有効性}

1 . 2 節にて概観してきた従来の検索手法では, 主とし て , 形容詞を検索クエリとしていることはすでに述べた とおりである. 複数の印象に対して产の度合いをユーザ が入力し，商品を検索する方法も提案されているが [村 上 10], これはユーザが求める商品のイメージを細かく 捉えることができる反面, ユーザの負担が大きくなって しまう．

弚こで本研究では, ユーザの自由な表現による入力を 可能とし, 弚れらの表現からユーザが所望する質感を微 細に捉えることができる検索手法として、さらさら」と いったオノマトペ (擬音語・擬態語の総称) に着目する . オノマトペは, 物体の状態や構造, 音の響きなどの感覚 イメージを直感的に表現できる言葉であり[筧 93] , 形容 詞よりもオノマトペの方が, 各素材の微細な質感を多樣 
に表現できるということも示されている[坂本 13] . 例え ば,「やわらかい毛布」といっても，実際には「ふわうわ した毛布」「ももこもこした毛布」「らかかかした毛布」な ど樣々に存在する .このように，人はオノマトペを用い ることで, 質感の微細な違いを短く簡潔に表現している 可能性がある．さらに，才ノマトペの方が，具体的に特 定のイメージを共通認識として想起しやすいことも報告 されている[小野 11]．乥して，オノマトペは感覚的な言 葉であるがゆえに, 弚の意味が直感的に理解し易いとさ れている [田守 98] .

オノマトペを構成する音韻と炎の感覚イメージに関し て，日本語を母語とする我々の間には共通の認識があり， ある共通のイメージを持った文字の組み合わせで，弚の イメージに関連する音や樣子を表している．このような 現象は「音象徵」と呼ばれ，音象徵によって喚起される 意味を「音象徵的意味」という [Hamano 98]．また，人 の快不快の評価がオノマトペの音韻に反映されるという 報告もある [渡邊 11] . 例えば , 音韻/s/は快 (例 .さらさ ら）と，音韻/z/は不快（例．ざらざら）と強く結び付く. したがって，オノマトぺを利用することで，ユーザの快 不快を含む視覚や触覚的な印象を抽出することができる．

乥こで本研究では, 従来研究て指摘されているオノマ 卜ペの特長に基づき, ユーザが所望する質感をもつ商品 を直感的に検索するためのクエリとして，オノマトペに 着目する. 光して，オノマトペの音韻に音象徵的に結び つく質感イメージを検索クエリとして応用する．本研究 は, 形容詞よりもオノマトペの方が検索クエリとして有 効性が高いことを示すことを主眼とするものではないが， オノマトペの強みを生かした手法の提案を目指す．

\section{4 オノマトペの工学的応用}

近年，オノマトペが表す意味情報を定量的に捉えよう とする研究があり, オノマトペの工学的応用を図る取り 組みがなされている.具体的には，素材の質感が，色彩 の影響を強く受けるという報告 [丹野 10] 考慮し，才ノ マトペ質感印象に適した色彩の提案も行われている [liba 12a, Iiba 12b, 土斐崎 13] . また，才ノマトぺの概念理解 を目的とし，Web テキストなどを用いて，オノマトペと 共起する単語を抽出し， これを基にオノマトペの意味情 報を推定している研究事例も見られる [奥村 03, 中部 10] . さらに,テキストデータ (Web 上にあるレシピやレビュー テキスト) に含まれるオノマトペを用いて，ユーザのク エリオノマトペとテキストのオノマトペとのマッチング によって，オノマトペに適したテキストを検索結果とし て返す情報検索システムも提案されている [カンウィパー 10] .

著者らは, オノマトペの音韻特徵と光の質感印象との 間には強い関連性があるという従来知見 [荒田 10 , 渡邊 11]に基づき，オノマトぺの音象徵性を利用し，才ノマ 卜ペが表す質感情報，すなわち，対象物の材質感や关の
感性的印象を定量的に評価するシステムを提案している [清水 14] .このシステムは, オノマトペを構成する全音 韻を網羅しており，例えば「ふわ」と「わふ」のように， 同じ音であっても 1 モ一ラ目と 2 モ一ラ目で喚起される 印象が異なるといったオノマトペ特有の性質も的確に反 映することができる．さらに，ユーザが創作した新たな 表現についても光の質感印象を定量化することができる． このシステムを応用することで, 人が視覚や触覚に関し て抱く，快不快を含む質感印象を，一言のオノマトペを 通して定量的に把握することができる．したがって本研 究では, 著者らが提案しているオノマトぺの質感評価シ ステム [清水 14] を応用した新たな手法を提案をする.

\section{2. 本提案手法の概要}

本研究では, 商品検索システムへの将来的応用のため の基礎技術として，任意のオノマトペが表す質感印象を 定量化する技術を応用し，画像のSIFT 特徵量（後述）, 画像の色特徵量，画像に対する印象を記述したテキスト を活用する手法を検討する．これにより，ユーザが商品 に対して求める材質感だけでなく, ユーザの感性的印象 や情動も直感的に把握することを試みる。

商品検索手法が抱えるユーザの要求の詳細な理解とい う課題に対して, 本研究では, 多感覚で感性的な情報を 含む質感 [小松 12] を表すオノマトペに着目することで 対処し, ユーザが所望する質感をクエリとした手法を提 案する.

大手ショッピングサイトのひとつである楽天市場*6 の 商品ページには, 商品画像とレビューテキストが含まれ ていることが多く，このふたつは顧客が商品を検索する 上で重要な要素であると考えられる. 乥こで本研究が扱 う検索対象として，画像と画像の印象を記述したテキス 卜を想定している．したがって，ユーザのクエリ文字列 に対し，画像と画像の印象を記述したテキストが持つ質 感情報を同時に考慮した検索手法を目指す．

本研究力提案する手法では,画像から質感に関する情報 を抽出するが，このとき，画像の特徴抽出として一般的に 用いられる SIFT 法 (Scale Invariant Feature Transform) [Lowe 04] を採用した . 本研究では, クエリとして言語 を用いるため，画像の意味内容を把握し，言語（クエリ） と画像のマッチングを行う必要がある.SIFT 法の利用 により，画像の意味内容を表す特徵べクトルか抽出され ることから，これと質感を表す言語を割り当てることで， 言語と画像の対応付けを容易に行うことができる．また， SIFT 特徵量と他の特徵量を組み合わせることで, 画像 検索精度が向上したと報告されていることから [Weijer 06, Varma 07] , 画像の色特徵量と SIFT 特徵量を組み合 わせて画像の特徵ベクトルを抽出し，产れらを質感を表 す言語に対応づけることで，画像およびテキストが持つ

*6 http://www.rakuten.co.jp/ 
質感情報の抽出を行う.さらに, $1 \cdot 1$ 節でも述べたとお り，独立行政法人中小企業基盤整備機構が実施した調査 により，商品購入において色が重視されていることが明 らかとなったことから, 本研究では画像特徵量として, 色 特徽量も採用することとした．本研究では，オノマトペ が表す質感印象を強調する色彩の推定手法 [liba 12a, Iiba 12b, 土斐崎 13] を応用し, オノマトペと画像の色特徵量 との類似度を算出することにより，オノマトペに適した 画像のランク付けを行う .

一般的な商品ページには, 商品の画像とともに商品の レビューテキストが含まれている、レビューテキストに は, 商品の仕樣などの具体的な属性に加え, 商品購入の 判断材料や，ユーザの選好情報なども含まれているため， 商品の質感に関する情報量が多く，有用性が高いと考え られる。

また，著者らが提案している，オノマトペの質感評価 システム [清水 14] を用いることで, ユーザが入力したク エリオノマトペに対し, 弚のオノマトペが表す質感印象 を 43 対の形容詞ごとに数值的に推定することができる 形容詞対に対する关れらの值と，画像の印象を記述した テキストに含まれる形容詞とのマッチングを図ることに より，オノマトペの印象に適した画像の検索を行う．し たがって, 本研究で提案する手法では, 画像やテキスト にあらかじめオノマトペをタグ付けする必要がなく, オ ノマトペを入力するだけで, 画像が検索される. 本研究 では, オノマトペが表す質感印象と強く結びつく形容詞 も同時に利用できるため，オノマトペが含まれていない テキストであっても検索が可能となり，テキスト内の形 容詞が持つ情報までも有効に活用することができる．

さらに, オノマトペの質感評価システム [清水 14] は, オノマトペを構成する音韻に着目し, ユーザが自由に創 作した新たなオノマトペに対しても評価が可能であるた め, このシステムを応用することで, 質感印象に適した 画像を検索できる.

以上のように本研究では, オノマトペが表す質感印象 を定量化する手法 [清水 14] を基盤とし，画像や画像の 印象を記述したテキストから抽出された質感印象を用い て, 入力したオノマトペが表す質感印象との類似度を算 出することにより，オノマトペが表す質感印象に合致し た画像をランク付けする．したがって本システムは, ク エリオノマトペが表す質感印象の定量化（機能 1)，画像 か持つ質感印象の抽出（機能2），オノマトペの質感印象 と画像の質感印象の類似度算出 (機能 3) の 3 つの機能 で構成される. 本システムの構成概要を図 1 に示す.各 機能の詳細については，次節以降で述べる．

\section{$2 \cdot 1$ オノマトペが表す質感印象の定量化}

本システムにおける 1 つ目の機能は, ユーザが入力し たクエリオノマトペが持つ質感印象の定量化である.本 機能は, [清水 14] カ提案するシステムを基盤とする .才

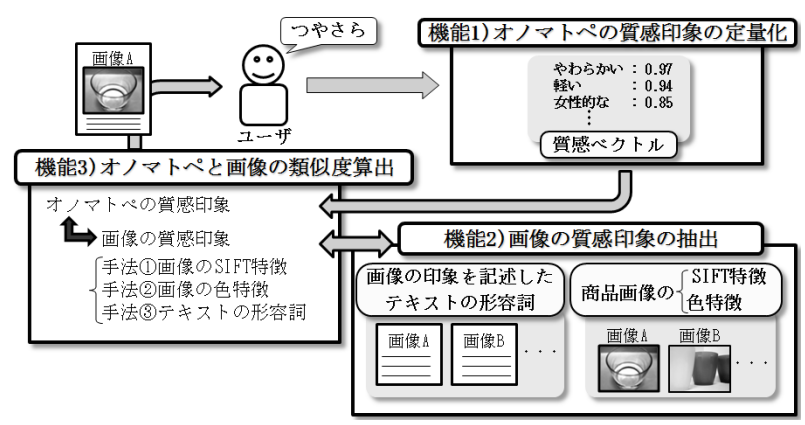

図 1 本システムの構成図

ノマトペによる質感評価システム [清水 14] の実行画面 を図 2 に示す。
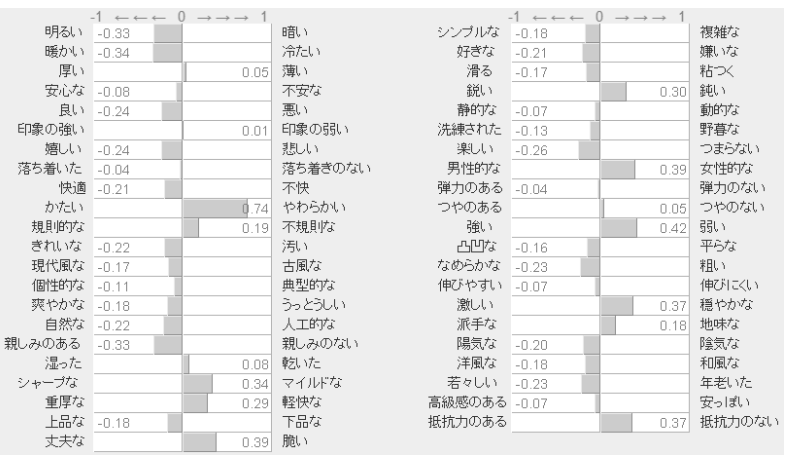

図 2 オノマトペによる質感評価システム (入力例 : ふわふわ)

[清水 14] は, オノマトペを構成する各音韻に関して， 兴の音韻がオノマトペが表す質感印象に与える影響の程 度を(以下，これを各音韻の゙ カテゴリ数量”と呼ぶ）を 心理実験によって定量的に収集し, 关の後, 数量化理論 の分析により形容詞尺度ごとに数值化している. 弚れら 数值の線形和によってオノマトペ产のものが表す質感印 象を定量的に推定している。評価尺度は，オノマトペと 結びつく質感印象を評価できる尺度であることか望まし いことから，『日本語語彙大系 [池原 97]』,『日本語大シ ソーラス [山口 03]』, 弚して触覚認知および視覚認知に 関する従来研究を参考に，触質感に関する評価尺度 43 対 を選定している。

[清水 14] ガ提案する，各音韻特性の印象予測モデルは 次のものである .

$$
\hat{Y}_{i}=X_{i 1}+X_{i 2}+X_{i 3}+\cdots+X_{i 13}
$$

式(1)において, $\hat{Y}_{i}$ はある形容詞尺度 $(i=1,2, \cdots, 43)$ の印象予測值, $X_{i 1} \sim X_{i 13}$ は各音韻要素のカテゴリ数 量 (各音韻特性が印象に与える影響の大きさ) を表し, $X_{i 1} \sim X_{i 5}$ は第 1 モ一ラの子音行, 濁音・半濁音, 拗音, 小母音, 母音, 語中標識の数量を, $X_{i 6}$ は第 1 モ一ラに 付く特殊語尾（撥音「ん」・促音「っ」・長音「一」）の数 量である.また， $X_{i 7} \sim X_{i 11}$ は第 2 モ一ラの子音行, 濁 音・半濁音, 拗音, 小母音, 母音, 語末標䇅の数量, $X_{i 12}$ 
は第 2 モーラに付く特殊語尾であり， $X_{i 13}$ は反復の数量 を表す [清水 14] .

また , 印象予測モデル式 (1) とカテゴリ数量の精度を 評価するために , 43 対の評価尺度での実測值と予測值を 比較した結果，被験者の印象評価を高い精度で予測でき ることが示されている [清水 14] .さらに, 新たに選定し た，慣習的オノマトペ 30 語および新奇的オノマトペ 18 語に関して，被験者の印象評価值とシステムの印象評価 値を比較した結果，提案システムが人の印象評価を高い 精度で推定できることを示している [清水 14] .

したがって，[清水 14] が提案するシステムを用いるこ とで, オノマトペが表す質感印象を評価尺度 43 対によっ て定量的に推定することができる．また，[清水 14] が提 案するシステムは, 新奇的オノマトペについても人の印 象に近い推定値を提示できることから，このシステムを 応用することで，ユーザが自由に創作した新たなオノマ 卜ペに対しても画像の検索が可能となる．次節では，画 像および画像の印象を記述したテキストが持つ質感印象 の抽出手法について述べる .

$2 \cdot 2$ 画像および画像の印象を記述したテキストが持つ 質感印象の抽出

本システムにおける $2 つ$ 目の機能は，画像および画像 の印象を記述したテキストが持つ質感印象の抽出を行う ことである

ここで本システムは, 将来的には実際の商品ページに 含まれるデータを活用することを前提としているが，今 回は，商品画像およびレビューテキストを想定したデー 夕を予め構築することとした . 本研究では, 画像として , 一般的な材質を揃えた素材画像を扱う『Flickr Material Database (以下 FMD)』における,「Metal/ Glass/ Plastic/

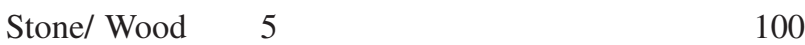
枚ずつ抽出し，計 500 枚を使用することとした . 商品に 使用される材質はこれら以外にもありうるが , 後述する 各画像の印象を回答する被験者負担などを考慮し，本研 究ではこれら $5 つ の$ 材質カテゴリのみを対象とすること とした . 例えば,「ツルツルした感じの家具が欲しい」と ユーザが考えた際，「ツルツル」したものは，金属，ガラ ス , プラスチック , 石 , 木など複数のカテゴリにまたがっ ているため, 本提案手法の検討においては, カテゴリご とに分けずに画像を扱う．また本研究では，ユーザがシ ステムに入力するクェリとして, 所望する商品の質感印 象を表すオノマトぺを想定している．よって，本研究の 提案手法は，アクセサリなど質感が重要な商品について は有効性が高いが, 質感よりも性能が重要なコンピュー 夕製品などにおいては有効性が低いと思われる。このよ うに, 将来的に実際の商品ページに応用する際には, 検 索対象として質感印象か購買に影響を与えやすい商品を 想定する .

また本研究では, 選定したこれらの画像を見て，光の
画像の印象を自由記述させる調査を行い，テキストを収 集した . テキスト収集に関する詳細は $2 \cdot 2 \cdot 3$ 節で述べる。

\section{$\S 1$ 画像の SIFT 特徵量を用いた質感印象抽出}

500 枚の画像から取り出す画像特徵の設計，および炎 の画像特徴を介した画像と形容詞のマッピングを次のよ うにして行った。

画像特徵には, 物体やテクスチャの画像認識で最も一般 的な, SIFT 特徵 [Lowe 99] に基づく Bag-of-Features 表 現 [Sivic 03] を用いた . 具体的には, 各画像 $(512 \times 384$ 画素) をグレースケールに変換した後, 画像上で規則正 しくとつた格子の各点にて, SIFT 特徵量 (128 次元) を抽 出する . 次に各点の特徵量を, 予め求めておいた同特徵 空間上のビジュアルワードのうち最近傍のものに分類し， 兴のときの各ビジュアルワードの出現頻度を, この画像 1 枚の特徵量とする．なおビジュアルワードは, 学習用 の画像集合に対し, 上と同じ方法で各画像から取り出し た SIFT 特徵の集合に $\mathrm{k}$ 平均クラスタリングを適用し， 512 個を選定する．以上の手続きにより，1 枚の画像の 画像特徵は，512 個の成分を持つベクトルとなる．

このように抽出する画像特徵と対応づける形容詞尺度 として , 43 対の形容詞尺度のうち，5 対の尺度（「明る い-暗い」「暖かい-冷たい」「印象の強い-印象の弱い」 「かたいーやわらかい」「自然な－人工的な」）を選んだ . これらの尺度は，画像の SIFT 特徵量と一般に対応が付き 易いと考えられる質感印象（「明るい－暗い」「かたいやわらかい」) と，必ずしも光うではないと思われるも の（「暖かい－冷たい」「印象の強い－印象の弱い」「自 然な一人工的な」）の両方を含むように選定を行った .

これら形容詞尺度と画像 (の画像特徵) とのマッピン グは, 人の手で作成した比較情報を用いた学習によって 求めた [Parikh 11] . 比較情報とは，画像 2 枚の組み合わ せに対し，各形容詞についてどちらの画像がより「妥当 か」を与えるもので, 例えば，形容詞尺度「明るい-暗 い」の場合，2 枚の画像のうちどちらがより“明るい” かを表す. 500 枚の画像の半分にあたる 250 枚を学習用 画像とし，この中の任意の 2 枚の組み合わせ多数に対し， 人手で上述の 5 つの形容詞尺度の比較情報を作成した この作業には、『Amazon Mechanical Turk』*7を用いた .

このように収集した学習用データを用い，画像（から 取り出した画像特徵）と 5 つの形容詞尺度間の関係を学 習させた . 学習は, 上述の画像特徵 512 次元の空間にお いて，学習データが与える比較情報をなるべく忠実に再 現するような同特徵空間の方向を，ランキングSVMに よって求めることで行った .この方法で, 各形容詞につ き一つの特徵空間のベクトルが定められる .このべクト ルは，各形容詞尺度の強弱を表現した画像特徵空間の方 向である.したがって, 新たな画像（例えば残り 250 枚 のうちの 1 枚) の形容詞尺度を, この画像から同じやり

*7 https://www.mturk.com/mturk/welcome 
方で画像特徵を取り出した後, これら 5 つのベクトルと の内積計算により取得することができる .

このように定めた画像と形容詞尺度のマッピングを使 い, 検索時には, 入力したオノマトペから求まる上述の 5 つの形容詞尺度と, データベースの画像 (FMD の画像

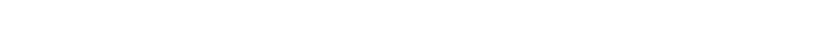
めることで, オノマトペが表す質感印象と最も良く整合 する画像を選び出すことができる．

\section{$\S 2$ 画像の色特徵量を用いた質感印象抽出}

本研究では, オノマトペが表す質感印象を強める色彩 を定量的に推定する手法 [Iiba 12a, Iiba 12b, 土斐崎 13] を採用することで, 画像の色特徵量からオノマトペが表 す質感印象に適した画像を検索することができると考え た . まず, オノマトペが表す質感印象を強める色彩の選 定方法について述べる。

色彩サンプルとして，色彩と产の色彩から想起される 印象が言語で対応付けられた『カラーイメージスケール [小林 01]』に揭載されている色彩 130 色から選定を行っ た . これらの色彩を, 11 種の色相および 4 種の色調の合 わせて 44 群に分類した [小林 01] . 各群には 2〜4 色の色 彩が含まれている. 各群から代表色を決定するための予 備調査として, 被験者 5 名の判断により, 光れの群 に割り当てられた色相および色調に相応しいと思われる 色彩を各群から 1 色ずつ回答させた .この結果, 43 群で 1 色, 1 群で 2 色が代表色として選定され, 計 45 色を使 用することとし，これらの色彩を，オノマトペと対応付 ける色彩サンプルとした .

オノマトペが表す質感印象に適した色彩を選定するた めには, 各色彩が持つ質感印象値を収集する必要がある. 乥こで, 各色彩の質感印象を調査するための心理実験を 行った、被験者 20 名を対象に，色彩を 1 色ずつ提示し， 本研究で使用する 43 対の形容詞尺度を用いて, 提示し た色彩から想起される質感印象を 7 段階 SD 法で回答さ せた . 各色彩に対して 20 名の被験者回答が得られ, 各色 彩の評価値の被験者間平均を算出し, 色彩の質感印象値 (色彩 45 色 $\times$ 評価尺度 43 対) を収集した。

本システムか推定するオノマトペが表す質感印象值と， 心理実験を介して得た 45 色の各色彩の質感印象値との 類似度を算出することにより, 入力されたオノマトペに 対して各色彩との類似度が与えられる. 類似度の高い色 彩であるほど, オノマトペが表す質感印象と合致してい ることになる。なお, 本研究では, 類似度としてコサイ ン類似度を採用した .この理由は, オノマトペおよび各 色彩の質感印象值を弚れ光れ 43 個の要素を持ったベク トルとして扱い, 43 次元の同一ベクトル空間上でオノマ トペと各色彩の距離を測定する際に, コサイン類似度が 有用であると判断したからである。

先行研究により, オノマトペが表す質感印象に適した 色彩の選定するシステム [Iiba 12a, Iiba 12b, 土斐崎 13] が開発され，このシステムの認知的妥当性が検証されて
いる．まず，オノマトペから想起される色彩を心理実験 によって収集し，このデータとシステムから得られた色 彩 (オノマトペに適した色彩) の比較を行っている.被 験者 10 名を対象に，30 語の各オノマトぺに適した色彩 を 22 個の色彩系統から 3 個を回答させた .ここで, 22 個の色彩系統とは, 45 色の色彩サンプルを光の色彩が持 つ質感印象值に基づいてクラスタ分析 (Ward 法) し, 22 系統に分類したものを指す.システムを介して 30 語の才 ノマトペに適した色彩系統の上位 5 個を計算し，これら の色彩系統に被験者が回答した 3 個の色彩系統のうちい ずれかが含まれている場合, 被験者回答とシステムの選 定色彩が一致したと判断した. オノマトペ 30 語に対し， システムの選定色彩が被験者の回答とどの程度一致する かを確認した . 弚の結果, 30 語中 19 語のオノマトペで, 7 名以上の被験者がシステムによる選定色彩と一致して おり, 8 語のオノマトペでは, 4〜6 名の被験者, 残り 3 語の才ノマトペでは，1３名の被験者がシステムの結果 と一致していた．したがって，30 語の全オノマトペで， システムの結果と被験者回答による色彩がほぼ一致して おり，このことから，オノマトぺが表す質感印象に適し た色彩選定手法の認知的妥当性が見られたと報告してい る [Iiba 12a, Iiba 12b, 土斐崎 13] . 以上により , ユーザが 入力したオノマトペが表す質感印象に適した色彩が類似 度と共に定量的に推定される。

続いて，使用する 500 枚の画像の色特徵量を抽出した . まず , 45 色の色彩サンプルを RGB 表色系で表現し [小林 01] , 各画像に関して, 画素の色情報に 45 色の RGB 值を 割り当てることで, ある画像について 45 色の画素出現頻 度か算出される.ある画素に 45 色の RGB 值を割り当てる 方法として，ある画素の RGB 值と 45 色の各色彩の RGB 値とのユークリッド距離を算出し , 45 色の中で最も距離 が近い値を持った色彩を，光の画素の色情報として割り当 てた . 画像のある画素Xの RGB 值が $\left(X_{R}, X_{G}, X_{B}\right)$ ， 45 色のある色彩 $\mathrm{Y}$ の RGB 值が $\left(Y_{R}, Y_{G}, Y_{B}\right)$ であると き,画素 $\mathrm{X}$ と色彩 $\mathrm{Y}$ のユークリッド距離 $d(X, Y)$ は, 以 下の式 (2)により求められる .

$$
d(X, Y)=\sqrt{\left(Y_{R}-X_{R}\right)^{2}+\left(Y_{G}-X_{G}\right)^{2}+\left(Y_{B}-X_{B}\right)^{2}}(2)
$$

以上の手続きにより, 500 枚の全ての画像について ,45 色の画素出現頻度が与えられる . これを各画像の色特徵 量として収集した .これらのデータを用いることで, 才 ノマトペが表す質感印象と最も良く整合する色彩の値を 持つ画像を選び出すことができる．

$\S 3$ 画像の印象を記述したテキストに含まれる形容詞を 用いた質感印象抽出

本システムでは, オノマトペと強く結びつく形容詞が 定量的に選ばれる。したがって，画像の印象を記述した テキストに含まれる形容詞を抽出することで, 形容詞を 介してオノマトペの印象に適した画像の検索が可能とな る.本研究では, 商品のレビューテキストを想定したデー 
表 1 テキスト 1 件あたりの単語情報

\begin{tabular}{c|c}
\hline 文字数 & 155.10 字 \\
延べ単語数 & 43.84 語 \\
形容詞の延へ語数 & 9.27 語 \\
オノマトペの延べ語数 & 1.33 語 \\
形容詞の出現割合 & $22.79 \%$ \\
オノマトペの出現割合 & $3.58 \%$ \\
\hline
\end{tabular}

タを予め構築することとした . 光こで，画像 500 枚につ いて，弚の印象を自由に記述したテキストデータを収集 するための実験を行った .

画像 500 枚に関する印象を調査することを目的とし， 20 歳から 24 歳の被験者 60 名 (男性 49 名, 女性 11 名) を対象に以下の心理実験を実施した . 画像 500 枚を 25 枚ずつの 20 グループに分け, 被験者 1 名当たり 25 枚の 画像の印象を回答させた . 具体的には, 画像を 1 枚ずつ 提示し, 光の素材の樣子から感じたことを自由に記述さ せた . 画像の提示順は，被験者毎にランダムとした . 実 験の結果，500 枚の各画像に対し，被験者 3 名分のテキ ストデータを得た . 各画像に対するテキストは, 3 名分 のデータを統合したものとする．したがって，テキスト は全部で 500 件である .

実験を介して収集したテキスト 500 件について，各テ キストに含まれる形容詞の抽出を行った . 形態素解析ソ

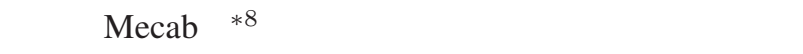
れる単語を解析した . 各テキストに含まれる形容詞・形 容動詞について, 本研究で使用する 43 対の形容詞尺度 と同義語であれば，弚の表現を形容詞尺度の形容詞に割 り当てた .なお，同義語の抽出は類語辞典『日本語大シ ソーラス - 類語検索大辞典 - [山口 03]』を用いて行った . 同義語の修正例は，規則正しい $\rightarrow$ 規則的な，重厚感 $\rightarrow$ 重厚な，軽い $\rightarrow$ 軽快な，伸びやすくはない $\rightarrow$ 伸びにく い, 乾燥した $\rightarrow$ 乾いた,である。

全テキストに含まれる単語情報を集計し，テキスト 1 件当たりの平均値として, 文字数・延べ単語数・形容詞 の延へ語数・形容詞の出現割合・オノマトペの延へ語数・ オノマトペの出現割合を算出したところ, 表 1 のように なった .なお, 形容詞 (オノマトペ) の出現割合とは, 延 べ単語数のうち形容詞 (オノマトペ) の延へ語数が占め る割合である .

分析の結果 , 全てのテキストには, 2 種類以上の形容詞 が含まれていることが確認された .さらに, 各テキスト に含まれる単語について，43 対の形容詞尺度と類義語で あれば, 兴の単語を形容詞尺度の表現に置き換えた .な お，類義語の抽出は, オンライン上の概念辞書『Wordnet ${ }^{* 9}$ を用いて行った . 全テキストに含まれる 601 語の異な り語について, 各単語を「Wordnet 検索」することで, 乥 の単語の類義語か検索される.検索された類義語中に ,43

*8 http://mecab. sourceforge.net/

*9 http://nlpwww.nict.go.jp/wn-ja/index.ja. html
対の形容詞尺度（もしくは形容詞尺度の同義語）が含ま れていれば, 弚の単語を形容詞尺度の表現に置き換えた。 このようにして，601 語の異なり語のうち 135 語を 43 対 の形容詞尺度にある形容詞に置き換えた .このとき，601 語にはオノマトペも含まれていたが, 本研究では, 画像 の印象を記述したテキストに含まれる形容詞を用いるこ とから ,オノマトペも形容詞に置き換えることとした .例 として、「つるつる」を「なめらかな」に,ここつごつ」を 「凸凹な」に置き換えた . 以上の手続きを行ったところ， テキスト 1 件当たりの形容詞数は 11.6 語となった .

各テキストに対し , 43 対の形容詞尺度の出現頻度が得 られたが , テキスト中にある尺度の両極の形容詞が出現 することで, 弚の尺度の質感印象が相殺されてしまう可 能性が考えられる，例として，「やわらかい輪郭である． ガラスだからかたい」というテキストには,「かたいやわらかい」尺度における両極の形容詞が含まれている． 乥こで, 形容詞尺度の両極形容詞が出現しているテキス 卜を集計したところ，全 500 件のうち 50 件か該当した .

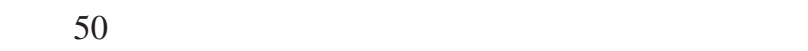
異なる場合は, 出現頻度が高い形容詞を優先とし, もう 一方の形容詞は使用しないこととした . また, 両極弚れ

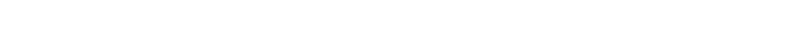
やわらかい」の両極形容詞が含まれていた場合，被験者 3 名に画像を提示し，この商品の印象が「どちらかと言え ば かたい”」「どちらかと言えば やわらかい”」「どち らとも言えない」のいずれに当てはまるかを回答しても らい, 3 名中 2 名が「どちらかと言えばかたい”」と回 答した場合は, 弚の形容詞を優先とし，もう一方の形容 詞は使用しないこととした。もし被験者 3 名が光れ光れ 「どちらかと言えば かたい”」「どちらかと言えばややわ らかい”」「どちらとも言えない」を回答した場合や，3 名中 2 名以上が「どちらとも言えない」を回答した場合 は，両極の形容詞をどちらも使用しないこととした . 以 上の手続きにより，各テキストに含まれる単語について， 同義語や類語による置き換え, 両極形容詞の調整を行っ たところ，各テキストに対し，43 対の形容詞尺度の出現 頻度が得られた. 光して, テキスト 1 件当たりの平均形 容詞数は 11.47 語となった. 表 2 に, 43 対の形容詞尺度 が含まれるテキスト数をまとめた．

表 2 より，43対の形容詞尺度のうち，「抵抗力のある抵抗力のない,以外の 42 対について, 光れらと対応する テキストが得られた .

テキストに含まれる形容詞尺度の出現頻度に基づき，光 のテキストを特徵づける形容詞尺度に重みを与える.本研 究では, 単語に重みを与える手法として TF-IDF 法 [德永 99]を用いた。TF-IDF 法では, ある文書に含まれる各単 語の出現頻度を表す TF (Term Frequency) と, 光の単語 が文書セット中のいくつの文書に含まれているかを表す DF (Document Frequency) の逆数の対数をとった IDF (Inversed DF) の 2 つの值を用いる . TF は $\mathrm{TF}(\mathrm{w}, \mathrm{D})=($ 文 
表 2 形容詞尺度が含まれるテキスト数

\begin{tabular}{|c|c|c|c|}
\hline 評価尺度 & 総数 & 評価尺度 & 総数 \\
\hline 暖かい-冷たい & 172 & 好きな-嫌いな & 63 \\
\hline 明るい-暗い & 95 & 洗練された-野暮な & 88 \\
\hline 派手な-地味な & 162 & きれいな-污い & 152 \\
\hline かたい-やわらかい & 248 & つやのある-つやのない & 173 \\
\hline 重厚な-軽快な & 199 & 湿つた-乾いた & 131 \\
\hline 自然な一人工的な & 182 & 凸凹な-平らな & 178 \\
\hline シンプルな-複雑な & 133 & 弾力のある-弾力のない & 40 \\
\hline 上品なー下品な & 64 & 伸びやすい-伸びにくい & 18 \\
\hline 静的な一動的な & 41 & なめらかな-粗い & 386 \\
\hline 洋風な-和風な & 49 & 滑る-粘つく & 28 \\
\hline 現代風な-古風な & 150 & 鋭い-鈍い & 135 \\
\hline 男性的な-女性的な & 55 & 厚い-薄い & 49 \\
\hline シャープな-マイルドな & 22 & 丈夫な-脆い & 136 \\
\hline 爽やかな-うっとうしい & 100 & 規則的な-不規則な & 65 \\
\hline 若々しい-年老いた & 67 & 快適-不快 & 61 \\
\hline 楽しい-つまらない & 63 & 安心な-不安な & 74 \\
\hline 嬉しい-悲しい & 25 & 印象の強い-印象の弱い & 23 \\
\hline 落ち着いた-落ち着きのない & 105 & 良い-悪い & 17 \\
\hline 個性的な-典型的な & 61 & 激しい-穏やかな & 44 \\
\hline 陽気な-陰気な & 61 & 抵抗力のある-抵抗力のない & 0 \\
\hline 強い-弱い & 83 & 高級感のある-安っぽい & 163 \\
\hline 親しみのある-親しみのない & 89 & & \\
\hline
\end{tabular}

書 $\mathrm{D}$ に含まれる単語 $\mathrm{w}$ の出現数)/(文書 $\mathrm{D}$ に含まれる全 単語の出現数 $), \operatorname{IDF}$ は $\operatorname{IDF}(\mathrm{w}, \mathrm{D})=\log (($ 文書セットにあ る全文書数 $) /($ 単語 $\mathrm{w}$ が含まれる文書数 $))$ によって与えら れる. 弚して，ある文書 D に含まれる単語 $\mathrm{w}$ の特徵度 $\mathrm{TF}-\mathrm{IDF}(\mathrm{w}, \mathrm{D})$ は , TF-IDF $(\mathrm{w}, \mathrm{D})=\mathrm{TF}(\mathrm{w}, \mathrm{D}) \times \operatorname{IDF}(\mathrm{w}, \mathrm{D})$ に よって求められる.

TF-IDF の值が高いほど , 兴の単語の特徵度が高い, す なわち，ある文書において光の単語が重要であることを 示している. 本研究では, あるテキスト D, ある単語 $\mathrm{w}$ (43 対の形容詞尺度の中のいずれかの形容詞) を用いて， 各形容詞に対して TF-IDF を求めることにより, 光のテ キストに対して各形容詞尺度がどれほど重要であるかを 測定した .これを全 500 件について行い，各テキストに 各形容詞尺度の重要度を対応づけたデータを収集した。 これらのデータを用いることで，2.1 節で述べたオノマ トペが表す質感印象と最も良く整合するテキストおよび 画像を選出することができる．

\section{$2 \cdot 3$ オノマトペの質感印象と画像の質感印象の類似度} 算出

本機能では, $2 \cdot 1$ 節で得られたオノマトペが表す質感 印象值と，2.2 節で得られた画像およびテキストから抽 出した質感印象の類似度を算出し, ユーザが入力したオ ノマトペが表す質感印象に適した画像をランク付けする 本研究では, 以下に示す 3 つの手法を用いて質感印象の 抽出を行った。

$\S 1$ 手法 1:画像の SIFT 特徵量を用いた質感印象抽出

手法 1 では, 画像の SIFT 特徵量を用いて, 画像 500 枚について , 43 対の形容詞尺度うち，5 対の尺度（「明る いー暗い」「暖かい-冷たい」「印象の強い-印象の弱い」 「かたいーやわらかい」「自然な-人工的な」) の共起確率 を対応付けている．したがって，2·1 節でオノマトペが
表す質感印象值が 43 対の形容詞尺度で予測されている ことから，この中から 5 対の尺度に関する質感印象値の みを取り出し, 5 対の形容詞尺度におけるオノマトペが 表す質感印象值と，各画像に与えられた 5 対の形容詞尺 度の共起確率を比較し, 弚れらがどれほど類似している かを測定する .ユーザが入力したクエリオノマトペが表 す質感印象值 (5 対の形容詞尺度を利用) を「クエリオ

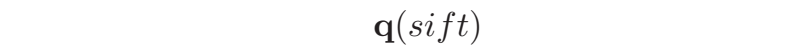
る質感印象値を $\mathbf{p}$ とすると， $\mathbf{q}(s i f t)=\left(p_{1}, \ldots, p_{5}\right)$ とな る.また，ある画像に与えられた 5 対の尺度の共起確率

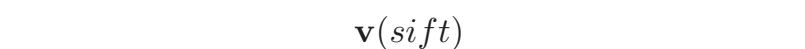
率を $r$ とすると， $\mathbf{v}($ sift $)=\left(r_{1}, \ldots, r_{5}\right)$ となる. $\mathbf{q}($ sift $)$ と $\mathbf{v}($ sift $)$ の類似度 $s(\mathbf{q}($ sift $), \mathbf{v}($ sift $))$ は, 式 (3) に示 すコサイン類似度によって求めるものとする .

$$
s(\mathbf{q}(\text { sift }), \mathbf{v}(\text { sift }))=\frac{\mathbf{q}(\text { sift }) \times \mathbf{v}(\text { sift })}{\mid \mathbf{q}(\text { sift })|\times| \mathbf{v}(\text { sift }) \mid} \text { (3) }
$$

式 (3) を用いて画像 500 件に対して , クエリオノマト ペとの類似度を算出し, 類似度に応じてクェリオノマト ペの質感印象に適した画像がランク付けされる.

$\S 2$ 手法 2:画像の色特徵量を用いた質感印象抽出

手法 2 では, オノマトペが表す質感印象值と 45 色の 各色彩の質感印象値との類似度を算出することで, クェ リオノマトペに対し, 各色彩との類似度を与える (以下， これを゙クェリオノマトペの色彩ベクトル”と呼ぶ）.画 像 500 枚について，45 色の RGB 值に基づき，各色彩の 画素出現頻度を算出し, 各画像の色特徵量を与えておく (以下，これを“画像の色彩ベクトル”と呼ゔ）。これに より, クエリオノマトペの色彩ベクトルと, 各画像の色 彩ベクトルを比較し, 乥れらがどれほど類似しているか を測定する.ユーザが入力したクェリオノマトペの色彩 ベクトルを $\mathbf{c}($ color $)$ とし, 各色彩との類似度を $a$ とする と， $c=\left(a_{1}, \ldots, a_{45}\right)$ となる . また，ある画像に与えられ

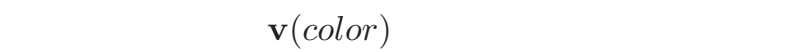
を $\mathrm{f}$ とすると, $\mathbf{v}($ color $)=\left(f_{1}, \ldots, f_{45}\right)$ となる . $\mathbf{c}($ color $)$ と $\mathbf{v}($ color $)$ の類似度 $s(\mathbf{c}($ color $), \mathbf{v}($ color $))$ は, 式 (4)に 示すコサイン類似度によって求めるものとする .

$$
s(\mathbf{c}(\text { color }), \mathbf{v}(\text { color }))=\frac{\mathbf{c}(\text { color }) \times \mathbf{v}(\text { color })}{\mid \mathbf{c}(\text { color })|\times| \mathbf{v}(\text { color }) \mid}(4)
$$

式 (4) を用いて画像 500 件に対して , クエリオノマト ペとの類似度を算出し, 類似度に応じてクエリオノマト ペの質感印象に適した画像がランク付けされる.

$\S 3$ 手法 3:画像の印象を記述したテキストに含まれる形 容詞を用いた質感印象抽出

手法 3 では, 各テキストに対して , 43 対の各形容詞尺 度の重要度を与えている．したがって，2.1 節でオノマ 卜ペが表す質感印象値が 43 対の形容詞尺度で予測され ていることから，オノマトぺの各形容詞における質感印 象值と，各テキストに与えられた各尺度の重要度を比較 し，光れらがどれほど類似しているかを測定する。ユー 
ザが入カたクエリオノマトペが表す質感印象值 (43 対 の形容詞尺度を利用) を「クエリオノマトペの質感ベク トル $\mathbf{q}(t e x t)\lrcorner と し ，$ 各尺度における質感印象値を $\mathrm{p}$ と すると， $\mathbf{q}($ text $)=\left(p_{1}, \ldots, p_{43}\right)$ となる．また，あるテキ ストに与えられた各尺度の重要度を「テキストの質感べ クトル $\mathbf{v}(t e x t)\lrcorner$ とし, 各尺度の重要度を $r$ とすると， $\mathbf{v}($ text $)=\left(r_{1}, \ldots, r_{43}\right)$ となる $\cdot \mathbf{q}($ text $)$ と $\mathbf{v}($ text $)$ の類 似度 $s(\mathbf{q}($ text $), \mathbf{v}($ text $))$ は, 式 (5) に示すコサイン類似 度によって求めるものとする。

$$
s(\mathbf{q}(\text { text }), \mathbf{v}(\text { text }))=\frac{\mathbf{q}(\text { text }) \times \mathbf{v}(\text { text })}{\mid \mathbf{q}(\text { text })|\times| \mathbf{v}(\text { text }) \mid}(5)
$$

式 (5) を用いて画像 500 件に対して，クエリオノマト ペとの類似度を算出し, 類似度に忍じてクェリオノマト ペの質感印象に適した画像がランク付けされる.

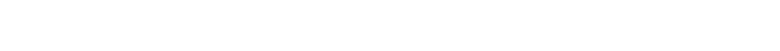
より精度の高い検索手法を検討する. 各手法の統合方法 として，例えば，手法 1 と手法 2 を統合する場合, クエ リオノマトペとある画像の類似度を手法 1 と手法 2 光れ 帒れで算出し，両者の平均類似度を求め，二れをある画 像に対する類似度とする．以上の手続きにより，本研究 では，3つの各手法に基づいた検索手法に加え，光れ光 れの手法の統合 (手法 1 と手法 2 , 手法 2 と手法 3 , 手 法 3 と手法 1 , 手法 1 と手法 2 と手法 3 ) に基づいた検 索手法の実装も可能となる.

\section{$2 \cdot 4$ 本システムによる検索結果例}

图 3 , 图 4 に本システムによる検索結果例を示す，

手法 1 (画像の SIFT 特徵量), 手法 2 (画像の色特徵 量)，手法3 (画像の印象を記述したテキストの形容詞) の各手法に基づいた検索システムを実装し , 各システム に同じオノマトペを入力した際の検索結果として，上位 5 位の画像を示している。

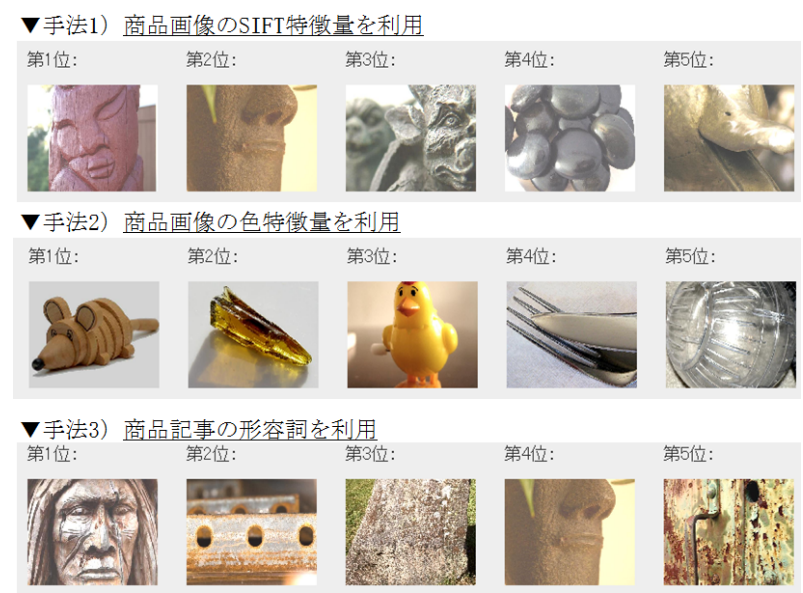

図 3 本システムの検索結果例（入力例：ごつごつ)

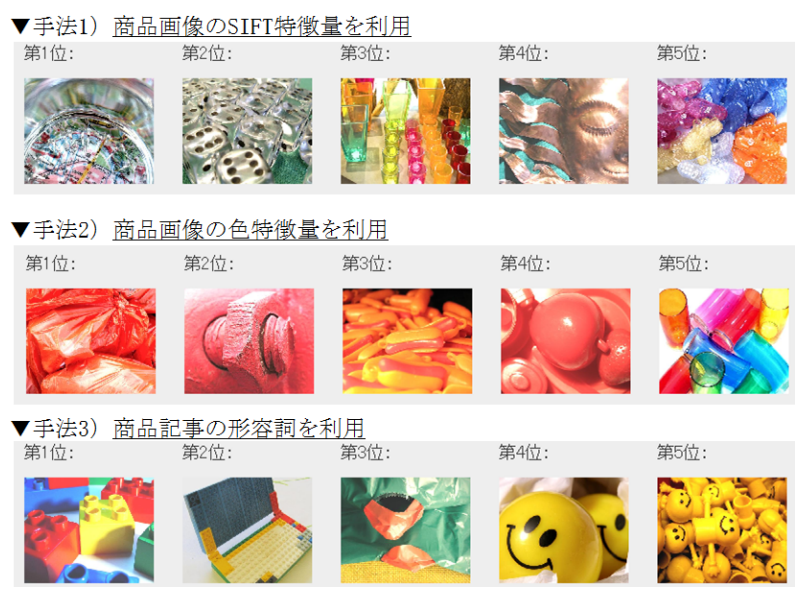

図 4 本システムの検索結果例（入力例 : ぴかぴか）

\section{3. 提案手法の評価}

本研究では, 商品検索システムへの将来的応用のため の基礎技術として，任意のオノマトペが表す質感印象を 定量化する技術を応用し，画像の SIFT 特徵量，画像の 色特徵量，画像に対する印象を記述したテキストを活用 する手法を提案した。

本手法の妥当性を検証するために，心理実験を介して被 験者から収集した正解データ (オノマトペと画像のSIFT 特徵量, オノマトペと画像の色特徵量, オノマトペと画 像の印象を記述したテキストの対応関係) を用いて, 本 手法の評価を行った .

評価は，情報検索で一般的に用いられている“，適合率 (precision) - 再現率 $($ recall $) \cdot \mathrm{F}$ 尺度 $(\mathrm{F}$ measure $)$ " [德永 99]を指標として行った . 適合率は, 正確性に関する指標 であり，上位 $\mathrm{N}$ 件の検索結果における正解データの割合 を指す．また，再現率は，網羅性に関する指標であり，全 正解データにおける上位 $\mathrm{N}$ 件で検索された正解データの 割合を指す．F尺度は，適合率と再現率の調和平均であり， 検索システムの正確性と網羅性を総合的に評価できる指 標である. 適合率を $\mathrm{P}$, 再現率を $\mathrm{R}, \mathrm{F}$ 尺度を $\mathrm{F}$ としたと

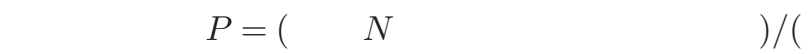
上位 $N$ 件の検索結果)， $R=$ (上位 $N$ 件における正解デ 一夕数 $) /($ 全正解デー夕数 $), F=2 /((1 / P)+(1 / R))$ と して与えられる

\section{$3 \cdot 1$ 評価用刺激の選定}

本システムでは, 画像 500 枚・画像の印象を記述したテ キスト 500 件をデータとして使用しているが , システム の評価では，このデータから選定した評価用刺激を用い ることとした .この理由は, 被験者から正解データとし てオノマトペと各画像の対応付けを収集するが，このと き 500 件全てに対して正解データを収集すると，被験者 への負担が大きくなり，評価結果に影響を及ぼすと考え たからである . 本研究では, 「Metal/ Glass/ Plastic/ Stone/ 
Wood」の 5 つの材質カテゴリから光れ光れ 100 枚ずつ 画像を抽出し，計 500 枚の画像を使用している．さらに， 画像の SIFT 特徵量による質感ベクトル，画像の色特徵 量による色彩ベクトル，画像の印象を記述したテキスト の形容詞による質感べクトルの 3 つの情報が付与されて いる．したがって，評価用刺激は，材質カテゴリおよび 先に述べた 3 つの情報に偏りがないように選定を行う必 要がある．弚こで, 評価用刺激を選定するために，まず， ある材質カテゴリ 100 件に対して , 各画像の質感べクト ル (画像のSIFT 特徵量を利用) について, 類似した質感 印象を持つ画像をまとめるために，質感べクトルを用い たクラスタ分析 (Ward 法, 距離の算出にはユークリッド 距離を使用) を行った . なお, クラスタ分析には統計解 析ソフト $\ulcorner\mathrm{R}\lrcorner * 10$ を使用した .この分析により，100 件 の画像を 10〜12 グループにまとめた . また , 同樣の手法 を用いて, 100 件の画像の色彩ベクトル (画像の色特徵 量を利用)，および画像の印象を記述したテキストの質 感ベクトル (テキストの形容詞を利用) についても, 類 似した色彩情報を持つ画像，および類似したテキストの 質感印象を持つ画像を 10〜12 グループにまとめた . 光 して, 画像のSIFT 特徵量により分類した各グループ, 色 特徵量により分類した各グループ, テキストの形容詞に より分類された各グループから最低 1 件選ばれるように 画像を選定し，最終的に，ある材質カテゴリの画像 100 件から 12 件を評価用刺激として選出した . 以上の手続 きを，他の材質カテゴリにも行うことで，画像 500 枚（ 材質カテゴリ $5 つ \times 100$ 件) から，画像 60 枚 (材質力 テゴリ $5 つ \times 12$ 件) を評価用刺激として選定した．

\section{$3 \cdot 2$ 正解データの収集}

本システムの妥当性を検証するために, 心理実験を介 して本システムの評価を行った . 心理実験では, 評価用 刺激となる画像から想起されるオノマトペを調査した .

22 歳から 24 歳の被験者 10 名 (男性 6 名, 女性 4 名) に対して画像を 1 枚ずつ提示し, 谷の画像の質感印象を オノマトペを用いて回答させた (複数回答可) . 画像の提 示順は, 被験者毎にランダムとし, 被験者 1 名当たり 60 枚の画像を割り当てた . 実験の結果, 評価用刺激の画像 60 枚の各画像に対し, 被験者 10 名が回答したオノマト ペが得られた . 評価用の全画像について, 被験者が回答 したオノマトペは合わせて 291 種類であった . 心理実験 によって得られた被験者の回答に基づいて正解データを 作成するが, 正解データは, 一定数以上の画像と才ノマ 卜ペが対応し, かつ, 弚の才ノマトペと画像の対応が客 観的に妥当であることが条件となる．したがって，ある 画像に対し，被験者が回答したオノマトペについて，他 の被験者も同じオノマトペを回答しているかを分析した . もし, 被験者 10 名中 3 名以上 (被験者の 3 割以上) があ る画像に対して同じオノマトペを回答していた場合, 光

\footnotetext{
*10 http://cran.r-project.org/
}

の画像とオノマトペの対応関係は妥当であると判断した . この処理を行った結果, 15 種類の才ノマトペが選定され た.続いて，これらのオノマトペから，一定数以上の画 像と対応する組み合わせとして, 10 枚以上の画像 (全 60 枚のうちの約 $16.7 \%$ 以上に相当）と対応関係を持つオノ マトペ 6 語を抽出した .この理由は, さまざまな手法の 精度をより明確に比較するためには, 正解データの数が 少ないことは好ましくないと考えたからである．選定さ れたオノマトペは，つるつる，ざらざら，てかてか，す ベすべ, ぴかぴか，ごつごつである．

\section{$3 \cdot 3$ 結 果と考察}

3 つの各手法と，各手法を統合した場合の検索システ ムの性能の比較を行ったところ, 次のような結果が得ら れた．オノマトペ 6 語の適合率，再現率，F尺度を，光 れ光れ表 3 , 表 4 , 表 5 , 表 6 , 表 7 , 表 8 に示す.さら に, 6 語分の平均適合率 $(\mathrm{P})$, 平均再現率 $(\mathrm{R})$, 平均 $\mathrm{F}$ 尺度 $(\mathrm{F})$ を, 各手法と複数手法を統合した場合で算出 し，表 9 にまとめた .なお表 9 に関して，検索上位 $\mathrm{N}$ 件 中，最も高い値を取った適合率，再現率，F 尺度には網 掛けを施した .

表 9 より, 検索結果上位 5 件においては, SIFT 特徵量 のみを用いる手法および SIFT 特徵量と画像の印象を記 述したテキストの形容詞を用いる手法が最も高い評価を 得た。一方，検索結果上位 15 件以上では，各手法を単 体で用いるよりも，全手法を統合した場合の方が，適合 率，再現率，F 尺度のいずれも高い值を得る結果となつ た . すなわち, 画像のSIFT 特徵と色特徵, 画像の印象を 記述したテキストの形容詞の全ての情報を用いて質感印 象を抽出した際の検索システムが, 最も高い精度を示す ことがわかった . 各才ノマトペ6語において，画像の色 特徵量を用いる手法を単独で使用した場合，他の手法に 比べて精度が低くなった，弚のため，他の手法と組み合 わせた場合には, 色特徵量が精度の低下を招く可能性も 考えられたが, 実際には, SIFT 特徵量と画像の印象を記 述したテキストの形容詞を組み合わせた手法よりも，全 手法を組み合わせた場合の方が優れた精度を示した .こ れは, SIFT 特徵・色特徵・形容詞の全情報を用いたこと で, 商品素材の視覚的な質感印象と触覚的な質感印象が 網羅的に抽出され, 兴の結果精度が向上したものと考え られる。

以上の結果から，全手法を統合した場合，検索結果上 位 15 件以上において適合率が最大で $66 \%$, 再現率が 最大で $82 \%$ を達成し, 本研究が提案する手法の妥当性が 示された .

\section{4. ま め}

商品検索システムへの将来的応用のための基礎技術と して, 本研究では, 画像の SIFT 特徵量, 画像の色特徵 
表 3 つるつるに対する適合率 $P$ と再現率 $\boldsymbol{R}$ と $\boldsymbol{F}$ 尺度

\begin{tabular}{c|ccc|ccc|ccc}
\hline \hline \multirow{2}{*}{$\begin{array}{c}\text { 検索上位 } \\
N \text { 件 }\end{array}$} & \multicolumn{3}{|c|}{$\begin{array}{c}\text { 手法 1 } \\
\text { SIFT 特徵量 }\end{array}$} & \multicolumn{3}{|c|}{$\begin{array}{c}\text { 手法 2 } \\
\text { 色特徵量 }\end{array}$} & \multicolumn{3}{|c}{$\begin{array}{c}\text { 手法 } 3 \\
\text { 形容詞 }\end{array}$} \\
\cline { 2 - 11 } & $\boldsymbol{P}$ & $\boldsymbol{R}$ & $\boldsymbol{F}$ & $\boldsymbol{P}$ & $\boldsymbol{R}$ & $\boldsymbol{F}$ & $\boldsymbol{P}$ & $\boldsymbol{R}$ & $\boldsymbol{F}$ \\
\hline 5 & 1.00 & 0.15 & 0.26 & 0.80 & 0.12 & 0.21 & 1.00 & 0.15 & 0.26 \\
10 & 0.90 & 0.27 & 0.42 & 0.60 & 0.18 & 0.28 & 0.90 & 0.27 & 0.42 \\
15 & 0.87 & 0.39 & 0.54 & 0.67 & 0.30 & 0.42 & 0.80 & 0.36 & 0.50 \\
20 & 0.85 & 0.52 & 0.64 & 0.65 & 0.39 & 0.49 & 0.85 & 0.52 & 0.64 \\
25 & 0.84 & 0.64 & 0.72 & 0.64 & 0.48 & 0.55 & 0.88 & 0.67 & 0.76 \\
30 & 0.87 & 0.79 & 0.83 & 0.60 & 0.55 & 0.57 & 0.83 & 0.76 & 0.79 \\
\hline \hline
\end{tabular}

表 4 ざらざらに対する適合率 $P$ と再現率 $R$ と $F$ 尺度

\begin{tabular}{c|ccc|ccc|ccc}
\hline \hline \multirow{2}{*}{$\begin{array}{c}\text { 検索上位 } \\
N \text { 件 }\end{array}$} & \multicolumn{3}{|c|}{$\begin{array}{c}\text { 手法 1 } \\
\text { SIFT 特徵量 }\end{array}$} & \multicolumn{3}{|c|}{$\begin{array}{c}\text { 手法 } \mathbf{3} \\
\text { 色特徵量 }\end{array}$} & \multicolumn{3}{|c}{$\begin{array}{c}\text { 手法 } 3 \\
\text { 形容詞 }\end{array}$} \\
\cline { 2 - 11 } & $\boldsymbol{P}$ & $\boldsymbol{R}$ & $\boldsymbol{F}$ & $\boldsymbol{P}$ & $\boldsymbol{R}$ & $\boldsymbol{F}$ & $\boldsymbol{P}$ & $\boldsymbol{R}$ & $\boldsymbol{F}$ \\
\hline 5 & 1.00 & 0.22 & 0.36 & 0.40 & 0.09 & 0.14 & 0.80 & 0.17 & 0.29 \\
10 & 1.00 & 0.43 & 0.61 & 0.50 & 0.22 & 0.30 & 0.80 & 0.35 & 0.48 \\
15 & 0.93 & 0.61 & 0.74 & 0.53 & 0.35 & 0.42 & 0.67 & 0.43 & 0.53 \\
20 & 0.80 & 0.70 & 0.74 & 0.45 & 0.39 & 0.42 & 0.60 & 0.52 & 0.56 \\
25 & 0.68 & 0.74 & 0.71 & 0.48 & 0.52 & 0.50 & 0.64 & 0.70 & 0.67 \\
30 & 0.60 & 0.78 & 0.68 & 0.47 & 0.61 & 0.53 & 0.57 & 0.74 & 0.64 \\
\hline \hline
\end{tabular}

表 5 てかてかに対する適合率 $P$ と再現率 $\boldsymbol{R}$ と $\boldsymbol{F}$ 尺度

\begin{tabular}{c|ccc|ccc|ccc}
\hline \hline \multirow{2}{*}{$\begin{array}{c}\text { 検索上位 } \\
N \text { 件 }\end{array}$} & \multicolumn{3}{|c|}{$\begin{array}{c}\text { 手法 1 } \\
\text { SIFT 特徵量 }\end{array}$} & \multicolumn{3}{|c|}{$\begin{array}{c}\text { 手法 } \mathbf{2} \\
\text { 色特徵量 }\end{array}$} & \multicolumn{3}{|c}{$\begin{array}{c}\text { 手法 } \mathbf{3} \\
\text { 形容詞 }\end{array}$} \\
\cline { 2 - 10 } & $\boldsymbol{P}$ & $\boldsymbol{R}$ & $\boldsymbol{F}$ & $\boldsymbol{P}$ & $\boldsymbol{R}$ & $\boldsymbol{F}$ & $\boldsymbol{P}$ & $\boldsymbol{R}$ & $\boldsymbol{F}$ \\
\hline 5 & 0.60 & 0.14 & 0.22 & 0.60 & 0.14 & 0.22 & 0.20 & 0.05 & 0.07 \\
10 & 0.60 & 0.27 & 0.38 & 0.60 & 0.27 & 0.38 & 0.30 & 0.14 & 0.19 \\
15 & 0.60 & 0.41 & 0.49 & 0.53 & 0.36 & 0.43 & 0.47 & 0.32 & 0.38 \\
20 & 0.50 & 0.45 & 0.48 & 0.40 & 0.36 & 0.38 & 0.45 & 0.41 & 0.43 \\
25 & 0.52 & 0.59 & 0.55 & 0.36 & 0.41 & 0.38 & 0.44 & 0.50 & 0.47 \\
30 & 0.47 & 0.64 & 0.54 & 0.33 & 0.45 & 0.38 & 0.43 & 0.59 & 0.50 \\
\hline \hline
\end{tabular}

表 6 すべすべに対する適合率 $P$ と再現率 $R$ と $F$ 尺度

\begin{tabular}{c|ccc|ccc|ccc}
\hline \hline \multirow{2}{*}{$\begin{array}{c}\text { 検索上位 } \\
N \text { 件 }\end{array}$} & \multicolumn{3}{|c|}{$\begin{array}{c}\text { 手法 1 } \\
\text { SIFT 特徵量 }\end{array}$} & \multicolumn{3}{|c|}{$\begin{array}{c}\text { 手法 } \mathbf{2} \\
\text { 色特徵量 }\end{array}$} & \multicolumn{3}{|c}{$\begin{array}{c}\text { 手法 3 } \\
\text { 形容詞 }\end{array}$} \\
\cline { 2 - 11 } & $\boldsymbol{P}$ & $\boldsymbol{R}$ & $\boldsymbol{F}$ & $\boldsymbol{P}$ & $\boldsymbol{R}$ & $\boldsymbol{F}$ & $\boldsymbol{P}$ & $\boldsymbol{R}$ & $\boldsymbol{F}$ \\
\hline 5 & 0.20 & 0.09 & 0.13 & 0.00 & 0.00 & 0.00 & 0.60 & 0.27 & 0.38 \\
10 & 0.10 & 0.09 & 0.10 & 0.20 & 0.18 & 0.19 & 0.60 & 0.55 & 0.57 \\
15 & 0.27 & 0.36 & 0.31 & 0.13 & 0.18 & 0.15 & 0.53 & 0.73 & 0.62 \\
20 & 0.30 & 0.55 & 0.39 & 0.15 & 0.27 & 0.19 & 0.50 & 0.91 & 0.65 \\
25 & 0.24 & 0.55 & 0.33 & 0.12 & 0.27 & 0.17 & 0.44 & 1.00 & 0.61 \\
30 & 0.27 & 0.73 & 0.39 & 0.13 & 0.36 & 0.20 & 0.37 & 1.00 & 0.54 \\
\hline \hline
\end{tabular}

量 ，画像の印象を記述したテキストを活用する手法を提 案した。

本研究の評価として，3つの手法を単体で用いる場合 や，各手法を統合して用いる場合の検索性能を評価した 結果，検索結果上位 15 件以上において，3つの手法を全 て統合した場合に最も高い精度が示され，適合率は最大
で $66 \%$ ，再現率は最大で $82 \%$ となった．このことから， 本研究が提案する手法は認知的に妥当であることが確認 された . 実際の商品ページへ応用する場合, 商品画像の背 景の影響を考慮する必要があるが, 本研究で用いた FMD 画像にも背景が含まれているため, 実際の商品画像へ応 用した場合でも, 本システムは妥当な検索結果を出力で 
表 7 ぴかぴかに対する適合率 $P$ と再現率 $R$ と $\boldsymbol{F}$ 尺度

\begin{tabular}{c|ccc|ccc|ccc}
\hline \hline \multirow{2}{*}{$\begin{array}{c}\text { 検索上位 } \\
N \text { 件 }\end{array}$} & \multicolumn{3}{|c|}{$\begin{array}{c}\text { 手法 1 } \\
\text { SIFT 特徵量 }\end{array}$} & \multicolumn{3}{|c|}{$\begin{array}{c}\text { 手法 2 } \\
\text { 色特徵量 }\end{array}$} & \multicolumn{3}{|c}{$\begin{array}{c}\text { 手法 3 } \\
\text { 形容詞 }\end{array}$} \\
\cline { 2 - 10 } & $\boldsymbol{P}$ & $\boldsymbol{R}$ & $\boldsymbol{F}$ & $\boldsymbol{P}$ & $\boldsymbol{R}$ & $\boldsymbol{F}$ & $\boldsymbol{P}$ & $\boldsymbol{R}$ & $\boldsymbol{F}$ \\
\hline 5 & 0.80 & 0.25 & 0.38 & 0.20 & 0.06 & 0.10 & 0.40 & 0.13 & 0.19 \\
10 & 0.60 & 0.38 & 0.46 & 0.20 & 0.13 & 0.15 & 0.40 & 0.25 & 0.31 \\
15 & 0.53 & 0.50 & 0.52 & 0.13 & 0.13 & 0.13 & 0.47 & 0.44 & 0.45 \\
20 & 0.55 & 0.69 & 0.61 & 0.20 & 0.25 & 0.22 & 0.45 & 0.56 & 0.50 \\
25 & 0.44 & 0.69 & 0.54 & 0.24 & 0.38 & 0.29 & 0.36 & 0.56 & 0.44 \\
30 & 0.40 & 0.75 & 0.52 & 0.23 & 0.44 & 0.30 & 0.37 & 0.69 & 0.48 \\
\hline \hline
\end{tabular}

表 8 ごつごつに対する適合率 $P$ と再現率 $R$ と $\boldsymbol{F}$ 尺度

\begin{tabular}{c|ccc|ccc|cccc}
\hline \hline \multirow{2}{*}{$\begin{array}{c}\text { 検索上位 } \\
N \text { 件 }\end{array}$} & \multicolumn{3}{|c|}{$\begin{array}{c}\text { 手法 1 } \\
\text { SIFT 特徵量 }\end{array}$} & \multicolumn{3}{|c|}{$\begin{array}{c}\text { 手法 2 } \\
\text { 色特徵量 }\end{array}$} & \multicolumn{3}{|c}{$\begin{array}{c}\text { 手法 3 } \\
\text { 形容詞 }\end{array}$} \\
\cline { 2 - 10 } & $\boldsymbol{P}$ & $\boldsymbol{R}$ & $\boldsymbol{F}$ & $\boldsymbol{P}$ & $\boldsymbol{R}$ & $\boldsymbol{F}$ & $\boldsymbol{P}$ & $\boldsymbol{R}$ & $\boldsymbol{F}$ \\
\hline 5 & 0.80 & 0.24 & 0.36 & 0.20 & 0.06 & 0.09 & 0.80 & 0.24 & 0.36 \\
10 & 0.60 & 0.35 & 0.44 & 0.10 & 0.06 & 0.07 & 0.80 & 0.47 & 0.59 \\
15 & 0.67 & 0.59 & 0.63 & 0.27 & 0.24 & 0.25 & 0.53 & 0.47 & 0.50 \\
20 & 0.60 & 0.71 & 0.65 & 0.30 & 0.35 & 0.32 & 0.60 & 0.71 & 0.65 \\
25 & 0.52 & 0.76 & 0.62 & 0.32 & 0.47 & 0.38 & 0.60 & 0.88 & 0.71 \\
30 & 0.47 & 0.82 & 0.60 & 0.33 & 0.59 & 0.43 & 0.57 & 1.00 & 0.72 \\
\hline \hline
\end{tabular}

表 9 全オノマトペに対する適合率 $\boldsymbol{P}$ と再現率 $\boldsymbol{R}$ と $\boldsymbol{F}$ 尺度

\begin{tabular}{|c|c|c|c|c|c|c|c|c|c|c|c|c|c|c|c|}
\hline \multirow{2}{*}{$\begin{array}{c}\text { 検索上位 } \\
N \text { 件 }\end{array}$} & \multicolumn{3}{|c|}{$\begin{array}{c}\text { 手法 } 1 \\
\text { SIFT 特徵量 }\end{array}$} & \multicolumn{3}{|c|}{$\begin{array}{l}\text { 手法 } 2 \\
\text { 色特徵量 }\end{array}$} & \multicolumn{3}{|c|}{$\begin{array}{l}\text { 手法 } 3 \\
\text { 形容詞 }\end{array}$} & \multicolumn{3}{|c|}{$\begin{array}{c}\text { 手法 } 1+3 \\
\text { SIFT + 形容詞 }\end{array}$} & \multicolumn{3}{|c|}{$\begin{array}{c}\text { 全手法 } \\
1+2+3\end{array}$} \\
\hline & $P$ & $R$ & $F$ & $P$ & $R$ & $F$ & $P$ & $R$ & $F$ & $P$ & $R$ & $F$ & $P$ & $R$ & $F$ \\
\hline 5 & 0.73 & 0.18 & 0.29 & 0.37 & 0.08 & 0.13 & 0.63 & 0.17 & 0.26 & 0.73 & 0.18 & 0.29 & 0.63 & 0.15 & 0.24 \\
\hline 10 & 0.63 & 0.30 & 0.40 & 0.37 & 0.17 & 0.23 & 0.63 & 0.34 & 0.43 & 0.63 & 0.30 & 0.40 & 0.67 & 0.33 & 0.44 \\
\hline 15 & 0.64 & 0.48 & 0.54 & 0.38 & 0.26 & 0.30 & 0.58 & 0.46 & 0.50 & 0.62 & 0.46 & 0.52 & 0.66 & 0.50 & 0.55 \\
\hline 20 & 0.60 & 0.60 & 0.58 & 0.36 & 0.34 & 0.34 & 0.58 & 0.60 & 0.57 & 0.59 & 0.59 & 0.58 & 0.63 & 0.62 & 0.61 \\
\hline 25 & 0.54 & 0.66 & 0.58 & 0.36 & 0.42 & 0.38 & 0.56 & 0.72 & 0.61 & 0.55 & 0.67 & 0.58 & 0.57 & 0.72 & 0.61 \\
\hline 30 & 0.51 & 0.75 & 0.59 & 0.35 & 0.50 & 0.40 & 0.52 & 0.80 & 0.61 & 0.53 & 0.77 & 0.61 & 0.54 & 0.82 & 0.64 \\
\hline
\end{tabular}

きるのではないかと考えられる．また, 実際の商品ペー ジでは広告の画像やテキストも存在するが, 多くの EC サイトにおいて, 商品画像と広告が重なり合う可能性は 低いため，広告の重畳の影響は小さいものと考えられる． さらに, 実際のレビューテキストに含まれる可能性のあ る, 触感の印象以外の形容詞ついては, 本研究て採用し ている質感に関連する 43 対の形容詞対と比較をし, 関 連がないと判断された場合には画像の特徵量抽出には用 いられないため，検索精度への影響は小さいものと考え られる。

しかしながら本研究では, 次の点に関する検証を行っ ていない . まず, FMD 画像から抽出した特徵量とオノマ 卜ペの質感印象を結び付ける手法は, 害際の商品ページ において，どのような商品カテゴリに対して有効である かという点である. 本提案手法は, 今回採用した素材画 像 (Metal/ Glass/ Plastic/ Stone/ Wood) に対して，少な
くとも一定の有効性を示したが, 本研究における提案手 法の評価は, あくまでも今回対象とした素材を用いた商 品に対して, 提案手法が有用である可能性を示すもので ある.したがって今後は, 実際の商品画像に対する検索 精度の検証が必要である.また, 今回採用していない素 材を用いた商品カテゴリについても，提案手法の有効性 を検証する必要がある。

続いて，画像の印象を記述したテキストを，実際の商 品ページのレビューテキストと想定して扱っている点で ある.乥こで, 両者の違いを検討するために, 本研究で収 集したテキストに対する形態素解析結果と, 実際の商品 ページのレビューテキストに対する形態素解析結果を比 較した.レビューテキストとして, 楽天市場にて販売さ れている, 本研究て採用した素材 (Metal/Glass/ Plastic/ Stone/ Wood) を用いて作られた商品（金属製鍋，ガラ ス製コップ, プラスチック製トレイ，石製鍋，木製携帯 
ケース) に対するレビュー計 1003 件を収集した．両者 を比較したところ，すべての素材カテゴリにおいて，実 験により収集したテキスト内で用いられている単語上位 10 件中平均 9 件は, オノマトぺの質感評価システムに用 いられている 43 尺度と関連する単語（柔らかい，滑ら かな，など）であった．光れに対し，すべての素材力テ ゴリにおいて，実際の商品ページのレビュ一内で用いら れている単語上位 10 件中平均 5 件は, 43 尺度と関連す る単語であったが, 弚れ以外の単語は, $($ 商品が) 欲し い/欲しくない」や「(価格が) 安い/高い」といった， 購買に関する単語であった ここのように, 本研究で収集 した，画像の印象を記述したテキストと実際の商品ぺー ジのレビューテキストでは, いずれもオノマトぺの印象 評価システムに用いられている形容詞尺度に基づいた質 感印象の抽出が可能であることはわかったが , 購買に関 する単語の使用という点においては, 両者の間に差異が 見られた .

また，現在の手法では，画像の印象を記述したテキス 卜の形容詞の使用不使用を判断する際，両極形容詞の両 方の形容詞が同頻度で出現している場合, どちらの形容 詞を採用するかを人手により選定する必要がある．した がって，実際の EC サイト等に応用する場合には，商品 カテゴリごとに関連する可能性の高い形容詞をあらかじ め選定しておくなどして，レビューテキストに含まれる 形容詞の使用不使用を自動的に判断する手法を検討する 必要がある。

さらに,本研究では,5つの材質カテゴリ (Metal/Glass/ Plastic/ Stone/ Wood) のみを採用しており，光の他にも 実際の商品に使われ得る一般的な材質 (布, 革, 紙, な ど) と強く結び付くと予想されるオノマトぺ(ふわふわ， もふもふ，など）を入力とした場合については検証を行っ ていない．したがって将来的には，本手法を実際の商品 検索へと応用するために，商品の材質カテゴリの拡充を 行い, ユーザの求めるあらゆる材質に対応できるような 改善が必要である

\section{謝辞}

本研究の成果は, 文部科学省科学研究費補助金新学術 領域研究「質感脳情報学 (23135510 及び25135713)」の 助成によるものである

\section{$\diamond$ 参 考 文 献 $\diamond$}

[Adomavicius 05] Adomavicius, G. and Tuzuhilin, A.: Toward the Next Generation of Recommender Systems: A survey of the Stateof-the-art and Possible Extensions, Transactions on Knowledge and Data Engineering, Vol. 17, No. 6, pp. 734-749 (2005)

[Broder 06] Broder, A.: The Future of Web Search: From Information Retrieval to Information Supply, in the 6th International Conference on Next Generation Information Technologies and Systems, pp. 362$363(2006)$

[Hamano 98] Hamano, S.: The Sound-Symbolic System of Japanese, Cambridge University Press, Cambridge (1998)
[Herlocker 04] Herlocker, J., Konstan, J., Terveen, L., and Riedl, J.: Evaluating Collaborative Filtering Recommender Systems, ACM Transactions on Information Systems, Vol. 22, No. 1, pp. 5-53 (2004)

[Heymann 08] Heymann, P., Koutrika, G., and Garcia-Molina, H.: Can Social Bookmarking Improve Web Search?, in the 1st ACM International Conference on Web Search and Web Data Mining, pp. 195-206 (2008)

[Iiba 12a] Iiba, S., Shiga, A., and Sakamoto, M.: A Method to Propose Color Associated with Onomatopoeia based on Sound Symbolism, in the 6th International Conference on Soft Computing and Intelligent Systems and the 13th International Symposium on Advanced Intelligent Systems, pp. 518-522 (2012)

[Iiba 12b] Iiba, S., Shimizu, Y., and Sakamoto, M.: A Method to Select Colors Appropriate for Tactile Onomatopoeia based on Sound Symbolism, in the International Workshop on Modern Science and Technology, pp. 127-131 (2012)

[Linden 03] Linden, G., Smith, B., and York, J.: Amazon.com Recommendation: Item-to-item Collaborative Filtering, IEEE Internet Computing, Vol. 7, No. 1, pp. 76-80 (2003)

[Lowe 99] Lowe, D. G.: Object Recognition from Local ScaleInvariant Features, in the IEEE 7th International Conference on Computer Vision, ICCV'99, pp. 1150-1157 (1999)

[Lowe 04] Lowe, D. G.: Distinctive Image Features from ScaleInvariant Keypoints, International Journal of Computer Vision, Vol. 60, No. 2, pp. 91-110 (2004)

[Parikh 11] Parikh, D. and Grauman, K.: Relative Attributes, in the IEEE 13th International Conference on Computer Vision, ICCV'11, pp. 503-510 (2011)

[Resnick 94] Resnick, P., Iacovou, N., Suchak, M., Bergstrom, P., and Riedl, J.: GroupLens: An Open Architecture for Collaborative Filtering of Netnews, in ACM 1994 Conference on Computer Supported Cooperative Work, pp. 175-186 (1994), Chapel Hill, NC

[Riecken 00] Riecken, D.: Introduction: Personalized Views of Personalization, Communications of the ACM, Vol. 43, No. 8, pp. 26-28 (2000)

[Sivic 03] Sivic, J. and Zisserman, A.: Video google: A text retrieval approach to object matching in videos, in the IEEE 9th International Conference on Computer Vision, ICCV '03, pp. 1470-1477 (2003)

[Varma 07] Varma, M. and Ray, D.: Learning the Discriminative Power-Invariance Trade-Off, in the IEEE 11th International Conference on Computer Vision, pp. 1150-1157 (2007)

[Weijer 06] Weijer, J. and Schmid, C.: Coloring Local Feature Extraction, in the 9th European Conference on Computer Vision, pp. 334-348 (2006)

[Yanbe 07] Yanbe, Y., Jatowt, A., Nakamura, S., and Tanaka, K.: Can Social Bookmarking Enhance Search in the Web?, in the 7th ACM/IEEE-CS Joint Conference on Digital Libraries, pp. 107-116 (2007)

[Ziegler 05] Ziegler, C., McNee, S., Konstan, J., and Lausen, G.: Improving Recommendation Lists Through Topic Diversication, in the 14th international conference on World Wide Web, pp. 22-32 (2005)

[カンウィパー 10] カンウィパーラートサムルアイパン, 中村聡 史, 渡辺 知恵美 : レシピ検索システムにおけるオノマトペとレシ ピ用語集合の関連付け, 情報処理学会研究報告. データベース・ システム研究会報告, Vol. 2010-DBS-150, No. 15, pp. 1-8 (2010)

[奥村 03] 奥村 敦史, 齊藤 豪, 奥村 学 : Web 上のテキストコーパ スを利用したオノマトペ概念辞書の自動構築, 情報処理学会研究 報告 . 自然言語処理, Vol. 23, pp. 63-70 (2003)

[荻野 06] 荻野晃大, 加藤 俊一: 感性検索システムの設計手法: 感性システムモデリング, 情報処理学会論文誌.データベース, Vol. 47, No. 4, pp. 28-39 (2006)

[加藤 05] 加藤 由花, 川口 賢二, 箱崎 勝也 : オンラインショッピン グを対象とした正確性と意外性のバランスを考慮したリコメン ダシステム, 情報処理学会論文誌. データベース, Vol. 46, No. 13, pp. 53-64 (2005)

[吉川 98] 吉川 歩: 感性情報処理と主観情報処理, Computer Today, Vol. 15, No. 1, pp. 34-39 (1998)

[栗田 92] 栗田 多喜夫, 加藤 俊一, 福田 有渼, 坂倉 あゆみ: 印象 語による絵画データベースの検索, 情報処理学会論文誌, Vol. 33, No. 11, pp. 1373-1383 (1992)

[荒田 10] 荒田 真実子, 今井むつみ, Katerina, K., 喜多壮太郎, 岡 
田 浩之 : 触覚の音象徵が与える幼児の物認識への影響, 日本認 知科学会第 27 回大会論文集, Vol. 27, pp. 294-299 (2010)

[高玉 13] 高玉 圭樹, 佐藤 史盟, 大谷 雅之, 服部 聖彦, 佐藤 寛之, 山口 智浩 : 別カテゴリ商品提示による好みの明確化を促す推薦 システム, 人工知能学会論文誌, Vol. 28, No. 2, pp. 210-219 (2013) [黑田 07] 黑田 英憲, 小澤朋之, 亀田 弘之 : 印象語に基づくWeb ページデザインシステムの構筑と年の評価, 電子情報通信学会技 術研究報告. TL, 思考と言語, Vol. 107, No. 387, pp. 19-24 (2007) [今中 98] 今中武, 三浦 康史, 松浦聰, 九津見 洋, 小澤順 : イン ターネット上のデータを対象とした感性検索方式, ヒューマンイ ンタフェイスシンポジウム論文集, Vol. 14, pp. 679-684 (1998)

[坂本 13] 坂本 真樹, 渡邊 淳司 : 手触りの質を表すオノマトペの 有効性 : 感性語との比較を通して, 日本認知言語学会第 13 回大 会発表論文集, Vol. 13, pp. 473-485 (2013)

[山口 03] 山口 翼 : 日本語大シソーラス - 類語検索大辞典 - , 大 修館書店, 東京 (2003)

[小松 12] 小松 英彦 : 質感の科学への展望, 映像情報メディア学 会誌, Vol. 66, No. 5, pp. 332-337 (2012)

[小野 11] 小野 正理, 坂本 真樹, 清水祐一郎：オノマトペによる 共感覚比喻か理解しやすいのはなぜか, 日本認知言語学会第 11 回大会発表論文集, Vol. 11, pp. 170-180 (2011)

[小林 01] 小林 重順 : カラーイメージスケール 改訂版, 講談社, 東 京 (2001)

[神嶌 08] 神嶌敏弘 : 推薦システムのアルゴリズム (2), 人工知 能学会誌, Vol. 23, No. 1, pp. 89-103 (2008)

[清水 08] 清水 拓也, 土方 嘉德, 西田 正吾: 発見性を考慮した協 調フィルタリングアルゴリズム, 電子情報通信学会論文誌 D, Vol. J91-D, No. 3, pp. 538-550 (2008)

[清水 14] 清水 祐一郎, 土斐崎 龍一, 坂本 真樹 : オノマトペごと の微細な印象を推定するシステム, 人工知能学会論文誌, Vol. 29, No. 1, pp. 41-52 (2014)

[村上 10] 村上 裕一, 中村 真吾, 橋本 周司 : ユーザの感性情報を 自動学習する商品検索支援システムの提案, 情報処理学会第 72 回全国大会講演論文集, Vol. 2, pp. 451-452 (2010)

[醍醐 95] 醍醐 元正, 中島 信之, 般若 裕子: 検索条件の自動変更 を組込んだ商品購入支援システムの構築, 日本ファジィ学会誌, Vol. 7, No. 2, pp. 380-389 (1995)

[丹野 10] 丹野 匡貴, 伊藤 紀子, 阪田 真己子 : 布の風合いを表す 感性語と視覚・触覚との関連, 日本認知科学会第 27 回大会発表 論文集, Vol. 27, pp. 643-648 (2010)

[池原 97] 池原 悟, 宮崎 正弘, 白井諭, 横尾 昭男, 中岩 浩巳, 小 倉 健太郎, 大山 芳史, 林 良彦: 日本語語彙大系, 岩波書店, 東京 (1997)

[中辻 13] 中辻 真, 藤原 靖宏, 内山 俊郎, 戶田 浩之 : 動的なユーザ 興味に対応したセマンティクスに基づく情報推薦手法, 人工知能 学会論文誌, Vol. 28, No. 6, pp. 457-467 (2013)

[中部 10] 中部文子, 渡辺 知恵美: 感性情報を利用したオノマト ペ学習システムの開発, 第 1 回データ工学と情報マネージメン 卜に関するフォーラム (DEIM2009), Vol. E5-1, (2010)

[田守 98] 田守育啓：日本語オノマトペ: 多樣な音と樣態の表現, 日本音響学会誌, Vol. 54, No. 3, pp. 215-222 (1998)

[渡邊 11] 渡邊 淳司, 加納 有梨紗, 清水祐一郎, 坂本 真樹: 触感覚 の快・不快と炎の手触りを表象するオノマトぺの音韻の関係性, 日本バーチャルリアリティ学会論文誌, Vol. 16, No. 3, pp. 367-370 (2011)

[土斐崎 13] 土斐崎 龍一, 飯場 咲紀, 及川 歩唯, 清水 祐一郎, 坂 本真樹：オノマトペによる画像色彩推薦, 日本バーチャルリア リティ学会論文誌, Vol. 18, No. 3, pp. 357-360 (2013)

[土方 04] 土方嘉徳: 情報推薦・情報フィルタリングのためのユーザ プロファイリング技術, 人工知能学会誌, Vol. 19, No. 3, pp.365-372 (2004)

[土方 07] 土方 嘉德: 嗜好抽出と情報推薦技術, 情報処理学会論 文誌, Vol. 48, No. 9, pp. 957-965 (2007)

[德永 99] 德永 健伸, 辻井潤一: 情報検索と言語処理 : 言語と計 算 5 , 東京大学出版会, 東京 (1999)

[服部 11] 服部 俊一, 高間 康史 : 推薦情報の多樣化に向けた価値 観推論手法の提案, 第 27 回ファジイシステムシンポジウム講演 論文集, Vol. 27, pp. 247-250 (2011)

[木本 99] 木本 晴夫 : 感性語による画像検索と炎の精度評価, 情 報処理学会論文誌, Vol. 40, No. 3, pp. 886-898 (1999)

[筧 93] 筧寿雄 : 一般語彙となったオノマトペ, 月刊言語, Vol. 22, pp. 38-45 (1993)

〔担当委員 : 山本 岳洋〕

2014 年 5 月 8 日 受理

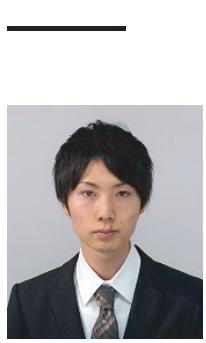

者 紹

土斐崎 龍一

2012 年 3 月電気通信大学電気通信学部人間コミュニケー ション学科卒業. 2014 年 3 月電気通信大学大学院情報理工 学研究科総合情報学専攻修士課程修了. 現在, 電気通信大 学大学院情報理工学研究科総合情報学専攻博士課程在学中。 人の認知と言語の能力に興味をもつ。擬音語・擬態語の総 称であるオノマトペの印象に合致した画像配色を推薦する 手法や，言語音と意味の結び付きである音象徵に着目した ブランドネーム印象の定量的評価手法の研究などに従事 .

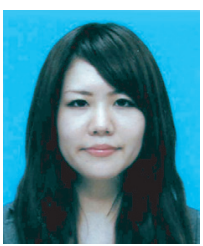

飯場 咲紀

2011 年 3 月電気通信大学電気通信学部人間コミュニケー ション学科卒業。2 013 年 3 月電気通信大学大学院情報理 工学研究科総合情報学専攻修士課程修了. 人の色彩認知に 興味をもつ、擬音語・擬態語の総称であるオノマトペの印象 に合致した色彩を推薦する手法や,テキストの感性イメー ジに合致した色彩とフォントを推薦する手法の研究などに 従事.

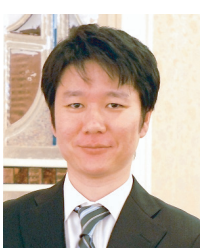

岡谷 貴之(正会員)

1999 年 3 月東京大学大学院工学系研究科博士課程修了 (計 数工学). 同年東北大学大学院情報科学研究科助手, 光の 後講師, 助教授 (准教授へ名称変更) を経て, 2013 年に教 授、現在に至る、コンピュータビジョンの研究に徉事、数 理統計学およひ数值最適化を理論的基礎に, 多視点幾何か ら物体認識までの幅広い応用に関心を持つ. 電子情報通信 学会, 情報処理学会, IEEE 等の会員

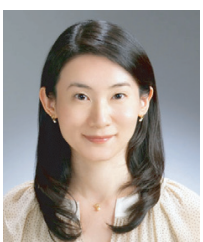

\section{坂本 真樹(正会員)}

1998 年 3 月東京大学大学院総合文化研究科言語情報科学 専攻博士課程了. 同専攻助手, 電気通信大学電気通信学部 人間コミュニケーション学科准教授を経て, 2010 年 4 月 上り同大大学院情報理工学研究科総合情報学専攻准教授。 言語処理学会, 日本感性工学会, 日本 VR 学会, 日本認知 言語学会, Cognitive Science Society 等各会員. 認知と言 語の関係に着目した応用研究に従事 . 博士 (学術) 。 